\title{
PENGARUH PROSES PEMBERIAN KREDIT TERHADAP MINAT NASABAH PADA PT BANK MANDIRI (PERSERO)TBKKANTOR CABANG KOMPLEK TASBI MEDAN
}

\author{
Pristiyono \\ Dosen Tetap Sekolah Tinggi Ilmu Ekonomi (STIE) Labuhanbatu
}

\begin{abstract}
ABSTRAK
Penelitian ini bertujuan untuk mengetahui dan menganalisis proses pemberian kredit terhadap minat nasabah pada PT Bank Mandiri (Persero)Tbk Kantor Cabang Tasbi Medan. Populasi dalam penelitian adalah nasabah kredit aktif PT Bank Mandiri (Persero)TbkKantor Cabang Komplek Tasbi Medanyang berjumlah 11.578 orang pada bulan April 2014.Dalam penelitian ini ukuran sampel ditentukan oleh bentuk uji statistika dengan menggunakan rumus Taro Yamane yang dikutip oleh Riduwan (2004), maka sampel dalam penelitian ini adalah 99.14 responden atau dapat dibulatkan menjadi 100 orang responden. Teknik pengambilan sampel menggunakan metode accidental sampling. Teknik analisis data menggunakan model analisis jalur dengan software AMOS 20.0.Hasil penelitian menunjukkan bahwa variabel persyaratan kredit berpengaruh langsung terhadap minat nasabah, variabel tingkat bunga kredit tidak berpengaruh langsung terhadap minat nasabah dan variabel jangka waktu kreditberpengaruh langsung terhadap minat nasabah.
\end{abstract}

\section{Kata Kunci: Persyaratan Kredit, Tingkat Bunga Kredit, Jangka Waktu Kredit.}

\section{Pendahuluan}

Angka pertumbuhan kredit di Indonesia setiap tahun semakin meningkat, hal ini menandakan tingkat persaingan bisnis jasa perbankan terus semakin ketat. Persaingan tersebut dianggap hanya terjadi antar sesama bank berhasil mengembangkan produk-produk keuangan baru. Persaingan dan perkembangan yang cukup pesat pada usaha perbankan tersebut menjadikan masing-masing lembaga perbankan harus berlomba untuk memenangkan pasar pesaingan bisnis. Persaingan antar bank tersebut tentunya akan lebih menguntungkan nasabah karena mereka dapat memilih berbagai jasa perbankan yang ditawarkan.

Perbankan mempunyai peranan menunjang pembangunan nasional dalamrangka meningkatkan pemerataan, pertumbuhan ekonomi dan stabilitas nasional. Dalam UndangUndang No. 10 tahun 1998 pasal 1 ayat (2) menyebutkanbahwa Bank Adalah Badan Usaha Yang Menghimpun Dana Dari Masyarakat Dalam Bentuk Simpanan Dan Menyalurkan Kepada Masyarakat Dalam Bentuk Kredit Atau Bentuk-Bentuk Lainnya Dalam Rangka Meningkatkan Taraf Hidup Rakyat Banyak.

Pemberian kredit kepada masyarakat dilakukan melalui suatu perjanjian kredit antara pemberi (bank) dengan penerima kredit (debitur) sehingga terjadi hubungan hukum antara keduanya. Seringkali yang ditemui dilapangan perjanjian kredit dibuat oleh pihak kreditur atau dalam hal ini adalah bank, sedangkan debitur hanya mempelajari dan memahaminya dengan baik. Namun demikian perjanjian kredit ini perlu mendapat perhatian khusus dari kedua belah pihak dikarenakan perjanjian kredit mempunyai fungsi yang sangat penting dalam pemberian, pengelolaan dan penatalaksanaan kredit tersebut dalam kesepakatan yang dilakukan antara debitur dengan kreditur, apabila debitur menandatangani perjanjian kredit yang dianggap mengikat kedua belah pihak dan berlaku sebagai undang-undang bagi keduanya.

Dalam menjalankan fungsi intermediasi sering kali terjadi keadaan yang tidak optimal dalam artian nasabah mengeluh sulitnya mengakses kredit dan sebaliknya bank mengeluh 
sulitnya menyalurkan kredit, ketidakoptimalan pemberian kredit memunculkan informasi yang tidak simetris, biaya transaksi dan timbulnya risikobank (Burhanuddin, 2006).

Proses pemberian kredit yang baik dari suatu lembaga perbankan dapat mempengaruhi keputusan nasabah, sehingga hal ini perlu menjadi pertimbangan lembaga keuangan atau perbankan dalam menyediakan jasa kredit. Berbagai macam alasan dan tujuan nasabah untuk memperoleh dana pinjaman suatu perbankan terutama nasabah yang kesulitan dana dalam permodalan bisnisnya.

Kebanyakan pelaku bisnis/masyarakat memutar usahanya dengan mengandalkan usahanya dengan modal sendiri dan untuk menghindari tingkat bunga kredit yang tinggi jika meminjam kepada perbankan, ada pula sebagian kecil yang berusaha menambah modalnya dengan melakukan pinjaman ke bank atau lembaga non bank (Dahlan, 2006).

Permasalahan yang terjadi dalam pemberian kredit terhadap nasabah antara lain bagaimana proses persyaratan kredit yang dipenuhi seorang calon nasabah, besar kecilnya tingkat bunga serta perubahan-perubahan tingkat suku bunga tidak stabil suatu lembaga keuangan dan jangka waktu pembayaran kredit yang ditawarkan kepada calon nasabah dalam perkembangannya masih menjadi masalah serius yang dihadapi antara perbankan dan nasabah.

Namun, dalam pelaksanaannya proses pemberian kredit secara umum masih diketemukannya kelemahan terutama dalam proses pemberian kredit seperti persyaratan kredit benar, informasi tidak akurat dari pihak manajemen, pemberian kredit tidak tepat untuk mencegah terjadinya kredit macet, tingkat bunga yang berubah-ubah, dan pemahaman nasabah terhadap jenis kredit yang akan diambil serta masalah jangka waktu pembayaran antara kedua belah pihak masih menjadi alasan mempengaruhi minat nasabah.

Proses pemberian kredit yang baik terhadap calon nasabah pada prinsipnya adalah agar pemberian kredit pada calon nasabah dapat mencapai sasaran sekaligus memperoleh pendapatan dan laba merupakan faktor berhasilnya kredit antara pihak bank dan calon nasabah. Untuk mengetahui seberapa jauh kemungkinan calon nasabah memenuhi kewajiban dan mengatur kemampuannya dalam melunasi hutang dan bunga, serta sekaligus usaha untuk memperkecil resiko yang timbul dari pemberian kredit.

Artikel ini bertujuan untuk mengetahui dan menganalisis proses pemberian kredit terhadap minat nasabah pada PT Bank Mandiri (Persero)TbkKantor Cabang Tasbi Medan.

\section{Kajian Pustaka \\ Penelitian Terdahulu}

Amanina (2011) melakukan penelitian langsung dengan judul "Evaluasi Terhadap Sistem Pengendalian Intern Pada Proses Pemberian Kredi Mikro" Studi kasus pada PT Bank Mandiri tbk Cabang Majapahit Semarang. Metode analisis data yang digunakan adalah analisis penerapan sistem pengendalian intern pada proses pemberian kredit dan analisis keefektifitas pengendalian intern pemberian kredit mikro. Hasil penelitian ini berkesimpulan bahwa PT Bank Mandiri Cabang Majapahit Semarang telah memenuhi unsur lingkungan pengendalian internal dengan adanya pembagian wewenang dan tanggung jawab yang jelas, unsur penaksiran resiko dimudahkan dengan adanya Loan Origination System (LOS) den Micro Banking Scoring System (MBSS) yang dapat mengelola data dengan baik sehingga kualitas kredit yang diterima dapat dipertanggungjawabkan serta unsur informasi dan komunikasi berjalan dengan baik. Namun, banyaknya aplikasi kredit yang diterima oleh PT Bank Manidri Cabang Majapahit Semarang tidak diimbangi dengan jumlah karyawan yang mencukupi pada posisi Mikro Kredit Analis (MKA), sehingga proses analisis kredit cenderung lama dan tidak sesuai dengan ketentuan. Oleh karena itu, keseimbangan antara sumber daya manusia yang kompeten dengan teknologi yang sesuai akan memaksimalkan kinerja perusahaan.

Miradewi (2014) melakukan penelitian dengan judul "Evaluasi Sistem Pengendalian Intern Pemberian Kredit pada PT Bank Pembangunan Daerah Bali Kantor Cabang Seririt". 
Hasil dari penelitian tersebut menunjukkan bahwa sistem pengendalian intern PT. Bank Pembangunan Daerah Bali Kantor Cabang Seririt sudah baik dan dikategorikan memadai. Adanya pemisahan tugas dan tanggungjawab dalam struktur organisasinya, sistem otorisasi dan prosedur pencatatan yang baik, serta praktik yang sehat dalam melaksanakan fungsi tiap unit organisasi. Hasil pengujian menunjukkan bahwa sistem pengendalian intern pemberian kredit pada PT. Bank Pembangunan Daerah Bali Kantor Cabang Seririt efektif dan diharapkan lebih memaksimalkan lagi penerapan sistem pengendalian intern dengan cara melakukan pemeriksaaan dan pemantauan terhadap proses pemberian kredit sesering mungkin, sehingga jika terjadi masalah dapat diketahui sejak dini.

\section{Minat Nasabah}

Minat pada hakekatnya adalah penerimaan hubungan antara diri sendiri dengan sesuatu di luar dirinya, semakin kuat atau semakin dekat hubungan tersebut maka semakin besar minatnya". Minat adalah pemusatan perhatian yang tidak sengaja yang terlahir dengan penuh kemauan dan tergantung dari bakat dan lingkungan. Minat adalah kecenderungan yang relatif menetap sebagai bagian diri seseorang, untuk tertarik dan menekuni bidang-bidang tertentu. Minat juga merupakan suatu kecenderungan subjek yang menetap untuk merasa tertarik pada bidang studi tertentu dan merasa senang untuk mempelajari materi itu. Dari berbagai pendapat tersebut dapat ditemukan adanya beberapa unsur pokok dalam pengertian minat, yaitu adanya perhatian, daya dorong tiap-tiap individu dan kesenangan.

Pasar nasabah terdiri dari semua individu dan rumah tangga yang membeli atau memperoleh barang dan jasa untuk konsumsi pribadi. Nasabah sangat beranekaragam menurut usia, pendapatan, tingkat pendidikan, pola perpindahan tempat dan selera. Adalah bermanfaat bagi para pemasar untuk membeda-bedakan kelompok nasabah yang memang berbeda dan mengembangkan produk dan jasa yang disesuaikan dengan kebutuhan nasabah itu. Menurut tujuan pembeliannya, konsumen/nasabahdapat dikelompokkan menjadi konsumen/nasabah akhir (individual) yaitu yang terdiri atas individu dan rumah tangga yang tujuan pembeliannya adalah untuk memenuhi kebutuhan sendiri atau untuk dikonsumsi.

\section{Bank Sebagai Lembaga Intermediasi}

Berdasarkan Undang-Undang RI No. 7 Tahun 1992 tentang Perbankan sebagaimana telah diubah dengan Undang- Undang No. 10 Tahun 1998 tentang Perbankan Pasal 3 antara lain : "Fungsi utama perbankan indonesia adalah sebagai penghimpun dan penyalur kepada masyarakat."

Menurut Bank Indonesia Tahun 2001, fungsi dunia perbankan dikenal sebagai lembaga intermediasi atau juga disebut lembaga financial internediary yang menyalurkan dana dari masyarakat yang surplus dana (penyimpan) kepada masyarakat yang kekurangan dana (peminjam). Bank merupakan lembaga kerpercayaan yang dipercaya masyarakat untuk menyimpan dan mengelola dananya, sehingga setiap rupiah yang disimpan masyarakat harus mampu dikembalikan, setiap masayarakat memerlukannya ditambah dengan bunga sesuai dengan diperjanjikan. Disisi lain bank harus menyakini bahwa setiap rupiah yang dipinjamkan dapat diterima kembali sesuai dengan waktu yang disepakati ditambah dengan bunga sesuai yang diperjanjikan.

\section{Pemahaman Tentang Kredit}

Kata kredit berasal dari bahasa latincredere yang berarti percaya atau to believe atau to trust sehingga yang dimaksud kredit adalah berarti memberikan nilai ekonomi kepada seseorang atau badan usaha berlandaskan kepercayaan (Muljono, 2001). Sedangkan menurut Undang-Undang No. Tahun 1998 Pengertian Kredit adalah : "Penyediaan uang atau yang dapat 
dipersamakan dengan itu berlandaskan perjanjian pinjam-meminjam (perjanjian kredit) dan kewajiban peminjam (nasabah) untuk melunasi pinjamannya setelah jangka waktu yang telah ditentukan dengan penyaluran bunga, imbalan atau pembagian hasil keuntungan".

Sehingga dari pengertian tersebut terkandung unsur-unsur yaitu :

a. Waktu yang menyatakan bahwa terdapat jarak antara persetujuan penyaluran kredit sampain dengan kredit lunas

b. Kepercayaan yang melandasi penyaluran kredit oleh phak kreditur kepada nasabah yang akan mengembalikan sesuai kesepakatan yang disetujui oleh kedua pihak.

c. Adanya penyerahan bahwa pihak kreditur menyerahkan kepada nasabah sejumlah nilai ekonomi yang harus dikembalikan setelah jatuh tempo

d. Adanya resiko yang mungkin timbul sehubungan dengan adanya jarak waktu antara saat memberikan dan pelunasan

e. Adanya perjanjian antara kreditur dan nasabah

f. Prestasi bahwa setiap kesepakatan terjadi antara bank dan nasabahnya mengenai suatu penyaluran kredit, maka pada saat itu pula akan terjadi suatu prestasi dan kontraprestasi.

\section{Proses dan Prosedur Penyaluran Program Kredit}

Seiring dengan semakin pesatnya persaingan usaha bank dalam penyaluran kredit, sehingga bank dituntut untuk lebih kreatif dalam menciptakan produk kredit yang disesuaikan dengan perkembangan dan kondisi kebutuhan masyarakat. Dengan beragamnya produk kredit ini, masyarakat konsumen mempunyai banyak kesempatan untuk memilih produk yang sesuai dengan kebutuhannya. Sehingga dengan demikian aktivitas perekonomian dalam masyarakat pun meningkat, yang juga akan mendorong peningkatan kinerja perbankan melakukan analisa berdasarkan 5 of credit yaitu Character, Capacity, Capital Condition dan Collateral.

a. Character adalah keadaan watak dan sifat cari calon peminjam baik dalam kehidupan pribadi maupun dalam lingkungan usaha. Penilaian character merupakan penilian terhadap kejujuran, ketulusan, ketajaman berfikir, logis, kepatuhan akan janji, kesehatan, kebiasaan, berani dengan /tanpa perhitungan risiko, suka/ tidak suka berjudi, kecakapan dalam mengelola usaha dan kemauan untuk membayar kembali hutang-hutangnya.

b. Capacity adalah kemampuan yang dimiliki calon nasabah untuk membuat rencana dan mewujudkan rencana itu menjadi kenyataan, termasuk dalam menjalankan usahanya guna memperoleh laba yang diharapkan, penelitian berkisar antara lain kemampuan dalam bidang manajemen, keuangan, pemasaran, tehnis.

c. Capital (modal) adalah dana yang dimiliki calon nasabah untuk menjalankan dan memelihara kelangsungan usahanya, tujuan penilaian untuk mengetahui permodalan, sumber-sumber dana/modal dan penggunaannya

d. Condition adalah keadaan sosial ekonomi suatu saat yang dapat mempengaruhi maju mundurnya usaha calon peminjam, penilaian untuk mengetahui sampai sejauh mana kondisi ekonomi itu berpengaruh terhadap kegiatan usaha calon peminjam dan bagaimana calon peminjam tersebut mengatasinya atau mengantisipasinya sehingga usahanya tetap hidup dan berkembang.

e. Collateral adalah barang-barang yang diserahkan calon nasabah sebagai jaminan terhadap kupedes yang akan diterimanya, tujuan penilaian adalah untuk mengetahui sampai sejauh mana risiko tidak terpenenuhinya kewajiban finansial kepada bank yang dapat tertutup oleh nilai barang jaminan yang diserahkan calon peminjam, penilaian terhadap barang jaminan meliputi jenis atau macam barang, nilai barang, lokasinya, bukti pemilikannya atau status hukumnya. Jaminan dapat berupa jaminan kebendaan seperti tanah dan bangunan atau benda bergerak seperti tanda bukti kepemilikan kendaraan bermotor dan sebagainya, nilai jaminan dapat menutup pokok dan bunga pinjaman. 


\section{Tingkat Bunga}

Menurut Kasmir, (2002:121) suku bunga bank dapat diartikan sebagai balas jasa yang diberikan oleh bank yang berdasarkan prinsip konvesional kepada nasabah yang membeli atau menjual produknya. Sukirno (2006:375) menyatakan suku bunga adalah bunga yang dinyatakan sebagai persentasi dari modal.Suku bunga mempunyai beberapa fungsi atau peran penting dalam perekonomian, yaitu :

a. Membantu mengalirkan tabungan berjalan ke arah investasi guna mendukung pertumbuhan perekonomian.

b. Mendistribusikan jumlah kredit yang tersedia, pada umumnya memberikan dana kredit kepada proyek investasi yang menjanjikan hasil tertinggi.

c. Menyeimbangkan jumlah uang beredar dengan permintaan akan uang dari suatu negara.

d. Merupakan alat penting menyangkut kebijakan pemerintah melalui pengaruhnya terhadap jumlah tabungan dan investasi.

\section{Jangka Waktu Kredit}

Setiap kredit yang diberikan memiliki jangka waktu tertentu, jangka waktu ini mencakup masa pengambilan kredit yang jelas disepakati. Jangka waktu tersebut bisa berbentuk jangka pendek, jangka menengah, atau jangka panjang (Totok dan Sigit, 2006), sebagai berikut :

a. Kredit jangka pendek, kredit yang memiliki jangka waktu pengembalian $\leq 1$ tahun yang digunakan untuk modal kerja.

b. Kredit jangka menengah, jangka waktu kredit antara 1 tahun sampai 3 tahun yang digunakan untuk investasi.

c. Kredit jangka panjang, kredit yang memiliki jangka waktu pengembalian lebih dari 3 tahun.

\section{Kerangka Konseptual}

Pemberian kredit yang tepat pada sasaran dan kesepakatan yang telah dicapai baik mengenai persyaratan kredit, tingkat bunga kredit yang disepakati dan jangka waktu pembayaran kredit akan meningkatkan aktivitas usaha kecil yang selanjutnya akan meningkatkan pendapatan usaha kecil, yang berarti bahwa usaha kecil tersebut berkembang. Hubungan tersebut dapat digambarkan dalam skema kerangka pemikiran sebagai berikut:

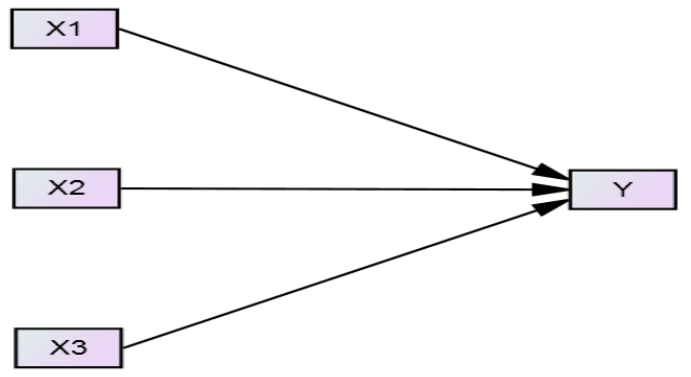

Sumber : Data Diolah, (Tahun 2014)

\section{Hipotesis Penelitian}

\section{Gambar 1. Kerangka Konseptual}

H1 : Persyaratan kredit berpengaruh pengaruh positif dan signifikan terhadap minat nasabah.

$\mathrm{H} 2$ : Tingkat suku bunga berpengaruh pengaruh positif dan signifikan terhadap minat nasabah.

H3 : Jangka waktu kredit berpengaruh pengaruh positif dan signifikan terhadap minat nasabah. 


\section{Metode Penelitian \\ Jenis Penelitian}

Pendekatan penelitian yang digunakan dalam penelitian ini adalah pendekatan kuantitatif, jenis penelitiannya adalah survei sedangkan metodenya deskriptif analitis. Data yang dikumpulkan melalui wawancara dan pengisian angket. Melalui penelitian ini diharapkan dapat diketahui pengaruh proses pemberian kredit terhadap minat nasabahPT Bank Mandiri (Persero)TbkKantor Cabang Tasbi Medan.

\section{Populasi dan Teknik Pengambilan Sampel}

Populasi adalah kelompok elemen yang lengkap, yang biasanya berupa orang, objek, transaksi atau kejadian dimana kita tertarik untuk mempelajari atau menjadi objek penelitian (Mudrajat, 2003). Populasi dalam penelitian adalah nasabah kredit aktif PT Bank Mandiri (Persero)TbkKantor Cabang Komplek Tasbi Medanyang berjumlah 11.578 orang pada bulan April 2014.Dalam penelitian ini ukuran sampel ditentukan oleh bentuk uji statistika dengan menggunakan rumus Taro Yamane yang dikutip oleh Riduwan (2004), digunakan untuk jumlah responden penelitian yang akan dijadikan sampel dalam penelitian ini sebagai berikut :

$$
\mathrm{n}=\frac{N}{N d^{2}+1}
$$

Dimana :

$$
\begin{array}{ll}
\mathrm{n} & =\text { Jumlah sampel } \\
\mathrm{N} & =\text { Jumlah populasi yang diketahui } \\
\mathrm{d} & =\text { Presisi yang ditetapkan } \\
\mathrm{n} & =\frac{11.578}{11.578 .0 .1^{2}+1} \\
\mathrm{n} & =\frac{11.578}{116.78}=99.14
\end{array}
$$

Maka sampel dalam penelitian ini adalah 99.14 responden atau dapat dibulatkan menjadi 100 orang responden.Teknik pengambilan sampel menggunakan metode accidental sampling, yaitu pengambilan sampel berdasarkan kebetulan yaitu siapa saja yang secara kebetulan bertemu dengan peneliti dapat digunakan sebagai sampel, bila dipandang orang yang kebetulan ditemui itu cocok sebagai sumber data.

\section{Hasil Penelitian}

Sebagai tahap awal dari metode analisis jalur (Path Analysis), maka dibuat terlebih dahulu diagram jalur. Dari hasil pengolahan data dengan program AMOS diperoleh diagram jalur disertai koefisien jalur sebagai berikut:

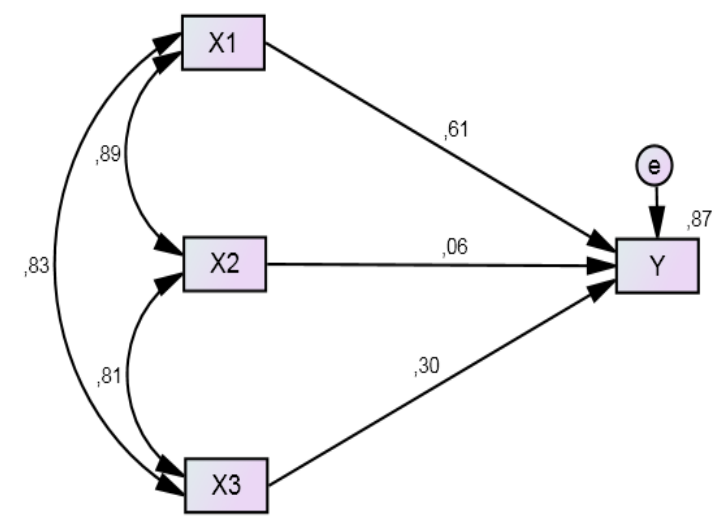




\section{Sumber : Data Diolah, (Tahun 2014)}

\section{Gambar 2. Hasil Analisis Jalur \\ Tabel 1. Regression Weights}

\begin{tabular}{|ll|llll|}
\hline & & Estimate & S.E. & C.R. & P \\
\hline Y <--- & X1 &, 618 &, 089 & 6,981 & $* * *$ \\
Y <--- & X2 &, 062 &, 082 &, 760 &, 447 \\
Y <--- & X3 &, 328 &, 075 & 4,359 & $* * *$ \\
\hline
\end{tabular}

\section{Sumber : Data Diolah, (Tahun 2014)}

\section{Pembahasan}

\section{Pembahasan Hasil Penelitian}

Berdasarkan pengujian hipotesis penelitian di atas, maka dapat dilakukan pembahasan secara rinci terkait hasil penelitianberdasarkan teoritis dan justifikasi teori sebagai berikut :

1) Berdasarkan hasil diperoleh nilai koefisien jalur variabel persyaratan kredit $\left(X_{1}\right)$ sebesar 0,618 dengan tingkat probabilitas sebesar 0,000. Sedangkan critical ratio (CR) sebesar $6,981>1,96$ dan nilai signifikansi $0,000<0,05$ maka dapat diartikan bahwa persyaratan kredit berpengaruh langsungterhadap minat nasabah. Oleh karena itu hipotesis pertama diterima. Hal ini berarti proses pemberian kredit dilakukan sesuai dengan prosedur dan ketentuan serta tata cara dalam pemberian kredit, persyaratan kredit. Kegiatan dalam proses persyaratan kredit tersebut memiliki kekhususan tersendiri, yaitu menawarkan kredit kepada calon nasabah melalui persyaratan tersebut memiliki resiko artinya Bank memiliki prinsip kehati-hatian dalam memberikan kredit didalam proses pelaksanaan pemberian kredit dengan memberikan persyaratan mudah dan cepat terhadap nasabah. Antara proses pemberian kredit tersebut memiliki hubungan yang sangat erat dengan pelayanan, yaitu bila pelayanan ditingkatkan maka hal tersebut akan meningkatkan resiko juga. Terjadinya hubungan tersebut memang suatu yang pasti terjadi dan tidak dapat dihindarkan. Misal, bank dalam menghadapi persaingan berusaha meningkatkan pelayanan yang diberikan agar produk yang ditawarkan tersebut terkesan mudah dijual atau lebih menarik minat nasabah.Akan tetapi bila persyaratan dipermudah sebagai bentuk peningkatan pelayanan kepada nasabah atau masyarakat, maka sebenarnya sejak saat itu pula tingkat resiko yang harus diterima oleh bank menjadi lebih tinggi. Begitu pula sebaliknya, apabila perhatian terhadap resiko lebih diutamakan, maka pelayanan yang dapat diberikan akan berkurang, sehingga produk yang ditawarkan akan menjadi lebih sulit untuk dipasarkan.

2) Berdasarkan hasil diperoleh nilai koefisien jalur variabel tingkat bunga kredit $\left(X_{2}\right)$ sebesar 0,062 dengan tingkat probabilitas sebesar 0,447 . Sedangkan critical ratio $(\mathrm{CR})$ sebesar $0,760<1,96$ dan nilai signifikansi 0,447>0,05 maka dapat diartikan bahwa tingkat bunga kredit tidak berpengaruh langsungterhadap minat nasabah. Oleh karena itu hipotesis pertama ditolak. Tingkat bunga kredit memiliki pengaruh yang tidak dapat dihindarkan dalam proses transaksi kredit, faktor tingkat bunga kredit atau suku bunga yang sesuai dengan kemampuan nasabah untuk memenuhi kewajibannya menggambarkan bahwa ada kaitan yang erat antara minat nasabah dalam pengambilan keputusan kredit dipengaruhi suatu bunga. Semakin rendahnya tingkat suatu bunga suatu lembaga perbankan akan menarik perhatian dan nasabah akan mempertimbangkan bahwa kredit dengan bunga rendah mampu meningkatkan minat masyarakat memilih kebutuhan kreditnya. Manajemen sebuah bank dituntut kecepatan dan ketepatan dalam merespon apa yang dibutuhkan masyarakat saat ini. Sebagai perusahaan jasa, perusahaan perbankan harus berorientasi pada perubahanperubahan yang terjadi pada konsumen. Perusahaan, khususnya perusahaan besar, pada umumnya melakukan riset dengan cermat tentang minat nasabah. 
3) Berdasarkan hasil diperoleh nilai koefisien jalur variabel jangka waktu kredit $\left(\mathrm{X}_{3}\right)$ sebesar 0,328 dengan tingkat probabilitas sebesar 0,000. Sedangkan critical ratio (CR) sebesar 4,359> 1,96 dan nilai signifikansi $0,000<0,05$ maka dapat diartikan bahwa jangka waktu kreditberpengaruh langsungterhadap minat nasabah.Oleh karena itu hipotesis pertama diterima, jangka waktu kredit memiliki pengaruh lebih dominan dibandingkan variabel lainnya sehingga dapat disimpulkan bahwa jangka waktu kredit seorang nasabah sangat menentukan putusan akhir minat nasabah untuk melanjutkan proses pemberian kredit berjalan lancar dan mencapai kesepakatan adalah mengenai jatuh tempo dari kredit itu sendiri. Saat ini lembaga keuangan perbankan berusaha menerapkan perubahan sistem atau kebijakan terhadap produk kreditnya dengan memberikan banyak pilihan jangka waktu kredit sesuai dengan kemampuan calon nasabah. Semakin panjang jangka waktu pinjaman, maka akan semakin tinggi bunganya, hal ini disebabkan besarnya kemungkinan resiko dimasa mendatang. Demikian pula sebaliknya jika pinjaman berjangka pendek, maka bunga relatif lebih rendah. Dapat disimpulkan bahwa antara pihak perbankan lembaga keuangan dengan calon nasabah/masyarakat dalam proses pemberian kredit harus memperhatikan dan memahami hak dan kewajiban dalam melakukan transaksi kredit.

\section{Kesimpulan} berikut :

Berdasarkan hasil penelitian dan pembahasan, selanjutnya ditarik kesimpulan sebagai

1. Variabel persyaratan kredit berpengaruh langsungterhadap minat nasabah.

2. Variabel tingkat bunga kredit tidak berpengaruh langsungterhadap minat nasabah.

3. Variabel jangka waktu kreditberpengaruh langsungterhadap minat nasabah.

Saran

Adapun saran-saran pada penelitian sebagai berikut :

1. Manajemen perbankan perlu memperhatikan persyaratan kredit yang akan ditawarkan kepada nasabah dengan mengusulkan untuk meninjau kembali persyaratan kredit yang selama ini diterapkan misalnya memberikan penjelasan kepada debitur seperti kemudahan persyaratan kredit, proses yang cepat dan data-data yang harus dilengkapi selanjutnya.

2. Manajemen perbankan juga perlu memperhatikan tingkat bunga kredit bank pesaing dengan mengusulkan ke kantor pusat meninjau tingkat bunga kredit agar disesuaikan dengan kemampuan calon debitur.

3. Manajemen perbankan sebaiknya melakukan terobosan-terobasan seperti : perbaikan informasi kredit, menganalisis data nasabah, pendekatan kepada masyarakat melalui eventevent kerjasama, ikut kampanye kredit dengan kerjasama pemerintah, koperasi dan pihak swasta sebagai peningkatan dibagian informasi untuk menjelaskan produk-produk kredit dan persyaratan tentang proses pemberian kredit, informasi bunga kredit dan jangka waktu kredit serta infromasi yang berhubungan kebijakan kredit melalui spanduk-spanduk atau brosur untuk mempermudah masyarakat memperoleh informasi kredit.

\section{Daftar Pustaka}

Undang-Undang No. 10 tahun 1998 tentang Perbankan pasal 1 ayat (2).

Undang-Undang RI No. 7 Tahun 1992 tentang Perbankan

Undang- Undang No. 10 Tahun 1998 tentang Perbankan Pasal 3

Bank Indonesia. 2001, Peraturan Bank Indonesia No. 3/21/PBI tahun 2001 Tentang Kewajiban Penyediaan Modal Minimum Bank Umum. Bank Indonesia.

Amanina. 2011. Evaluasi Terhadap Sistem Pengendalian Intern Pada Proses Pemberian Kredi Mikro" Studi kasus pada PT Bank Mandiri tbk Cabang Majapahit Semarang.Skripsi Program Sarjana (SI) pada Program Sarjana Ekstensi Fakultas Ekonomi Universitas Diponegoro. 
Burhanuddin, Abdullah. 2006. Jalan Menuju Stabilitas, Mencapai Pembangunan Ekonomi Berkelanjutan, Jakarta, LP3ES, Cetakan Kedua.

Dahlan, Siamat. 2001. Manajemen Lembaga Keuangan, Penerbit Salemba Empat, Jakarta.

Kasmir. 2002. Bank dan Lembaga Keuangan Lainnya. Edisi Revisi 2002. Jakarta: PT. Raja Grafindo Persada.

Miradewi. Dkk. 2014. Evaluasi Sistem Pengendalian Intern Pemberian Kredit pada PT Bank Pembangunan Daerah Bali Kantor Cabang Seririt. e-Journal S1 Ak Universitas Pendidikan Ganesha Jurusan Akuntansi Program S1 (Volume: 2 No: 1 Tahun 2014).

Mudrajad, Kuncoro. 2003. Metode Riset untuk Bisnis \& Ekonomi, Jakarta, Erlangga

Muljono, Teguh Pujo. 2001, Manajemen Perkreditan Bagi Bank Komersiil, Yogjakarta, BPFE, Edisi Keempat, Cetakan Pertama.

Riduwan, 2004. Metode Dan Teknik Menyusun Tesis. Penerbit Alfabeta Bandung. Sukirno, Sadono. 2000. Makroekonomi Modern. Jakarta : PT. Raja Grafindo Persada Totok Budisantoso, Triandaru Sigit. 2006. Bank dan Lembaga Keuangan Lain. Jakarta : Salemba Empat. 